\title{
Detection of larvae of Toxocara canis in milk: an experimental study in rabbits
}

\author{
Detecção de larvas de Toxocara canis em leite: \\ um estudo experimental em coelhas
}

\author{
Vamilton Alvares Santarém ${ }^{1 *}$; Célia Fátima Silva Exposto²; \\ Lívia Magosso Ramires ${ }^{3}$; Lundia Luara Cavalcante Bin³; Guita Rubinsky-Elefant; \\ Cecília Braga Laposy ${ }^{1}$; Rosa Maria Barilli Nogueira ${ }^{1}$
}

\begin{abstract}
Toxocariasis, caused most commonly by Toxocara canis, is an important cosmopolitan zoonosis. Paratenic hosts have been employed to provide knowledge regard to the transmission of toxocariasis. Transmammary transmission in murine experimentally infected was observed based on the recovery of larvae from the tissue. The aim of this study was to evaluate the possibility of transmammary transmission of Toxocara canis in rabbits by detecting larvae directly in milk. Seventeen sexually mature virgin white New Zealand female rabbits were divided into two groups. Twelve animals were orally inoculated with 1,000 T. canis embryonated eggs (infected group), and five animals remained uninfected (control group). One month following the infection, the females were mated. Manual collection of $500 \mu \mathrm{L}$ of milk from each rabbit was performed on days $+7,+14$ and +21 of lactation for three consecutive lactations. The recovery of larvae was determined via a centrifuge-sedimentation technique using ether and formalin solutions. ELISA test was run to confirm the production of anti-T. canis antibodies (IgG) by infected rabbits. The presence of larvae was observed in milk samples from 5 (41.7\%) of the 12 infected rabbits. The total number of recovered larvae was 20, ranging from 1 to 4 larvae per lactation/rabbit. Larvae were recovered exclusively on days 7 and 14 of lactation. Recovery was verified in different lactations. No significant difference was observed with respect to the number of larvae either in the same lactation period or in different lactation periods. Anti-T. canis antibodies were detected in all infected rabbits. In conclusion, the presence of larvae in rabbit milk samples suggests the possibility of galactogenic transmission of $T$. canis in paratenic hosts. Moreover, the technique employed in this study allows for the recovery of larvae directly from milk.
\end{abstract}

Key words: Toxocariasis, lactation, diagnosis

\section{Resumo}

Toxocaríase, causada geralmente pelo Toxocara canis, é uma importante zoonose de distribuição mundial. Hospedeiros paratênicos têm sido utilizados para obtenção de informações sobre a transmissão de T. canis. A transmissão transmamária em murinos infectados experimentalmente foi observada com

\footnotetext{
1 Médicos Veterinários, Profs. de Mestrado em Ciência Animal, Hospital Veterinário, Universidade do Oeste Paulista, UNOESTE, Presidente Prudente, São Paulo, SP, Brasil. E-mail: vamilton@unoeste.br; claposy@unoeste.br; rosa@unoeste.br

2 Discente de Graduação em Ciências, Discente de Mestrado em Ciência Animal, UNOESTE, Presidente Prudente, São Paulo, SP. Brasil. E-mail: celiafexposto@gmail.com

3 Médicas Veterinárias, Discentes de Mestrado em Ciência Animal UNOESTE, São Paulo, SP, Brasil. E-mail: celiafexposto@ gmail.com; livinhamagosso@hotmail.com; lundia.bin@hotmail.com

4 Farmacêutica Bioquímica, Laboratório de Seroepidemiologia e Imunobiologia, Instituto de Medicina Tropical de São Paulo, Universidade de São Paulo, USP, São Paulo, SP, Brasil. E-mail: guitare@usp.br

* Author for correspondence
} 
a recuperação de larvas. O objetivo do presente estudo foi de avaliar a possibilidade de transmissão transmamária de Toxocara canis em coelhos, pela detecção direta de larvas no leite. Dezessete coelhas (Nova Zelândia branca) púberes e virgens foram distribuídas em dois grupos. Doze fêmeas foram infectadas com 1000 ovos embrionados de T. canis (Grupo Infectado), por via oral, enquanto outras cinco coelhas foram mantidas sem infecção (Grupo Controle). Um mês após a inoculação, as coelhas foram acasaladas. Nos dias $+7,+14$ e +21 após o nascimento dos filhotes, foram coletados, por ordenha manual, $500 \mu \mathrm{L}$ de leite, em três lactações consecutivas. A recuperação de larvas foi determinada pelo uso da técnica de centrífugo-sedimentação com formol-éter. A técnica de ELISA foi empregada para confirmar a produção de anticorpos (IgG) anti-T. canis pelas fêmeas infectadas. Observou-se a presença de larvas em cinco das doze $(41,7 \%)$ coelhas por amostra. As larvas foram recuperadas exclusivamente nos dias $+7,+14$ de lactação. A detecção foi observada em diferentes lactações. Não houve diferença significativa entre o número de larvas na mesma lactação ou entre as diferentes lactações. Anticorpos anti-T. canis foram detectados em todas as coelhas infectadas. Em conclusão, a presença de larvas no leite de coelhas sugere a possibilidade de transmissão lactogênica em hospedeiros paratênicos. Ademais, a técnica empregada no estudo permite a recuperação de larvas diretamente do leite.

Palavras-chave: Toxocaríase, lactação, diagnóstico

\section{Introduction}

The causal agents of human toxocariasis are the ascarid nematodes (roundworms) Toxocara canis and $T$. cati, whose hosts are dogs and cats, respectively. However, T. canis is the most commonly studied agent in experimental infections using animal models (SANTARÉM; RUBINSKYELEFANT; FERREIRA, 2011).

In dogs, T. canis is transmitted most commonly via the placenta; however, other routes of transmission also occur, including the ingestion of embryonated eggs in the soil, the ingestion of paratenic hosts, and the ingestion by puppies of milk infected with larvae from nursing bitches (RUBINSKY-ELEFANT et al., 2010).

Humans represent an accidental host of $T$. canis, whereby transmission occurs via the ingestion of eggs present either in soil or on dog hair or via the ingestion of undercooked or raw meat from paratenic hosts, including ruminants (ESPAÑA et al., 1993; ALDAWEK et al., 2002; YOSHIKAWA et al., 2011; PARK et al., 2012) and birds (MORIMATSU et al., 2006). In Argentina, a case report describing an infected premature child presenting with an ophthalmic disturbance caused by $T$. canis larvae suggests that toxocariasis can be transmitted congenitally to humans (MAFFRAND et al., 2006).
The galactogenic transmission of $T$. canis to man has not been reported in the literature. However, studies have demonstrated that via milk maternalneonatal transmission of larvae can occur in experimentally infected mice, based on the recovery of larvae from the tissue of the newborn animals (REITEROVÁ; TOMASOVICOVÁ; DUBINSKÝ, 2003; JIN; AKAO; OHTA, 2008; DIAS et al., 2010). Nevertheless, information regard to recovery of larvae directly from milk in paratenic hosts is scarce in literature.

Based on these statements, the aim of the current study was to recover $T$. canis larvae directly from milk samples collected from experimentally infected rabbits.

\section{Material and Methods}

\section{Animals}

Seventeen sexually mature virgin white New Zealand female rabbits (two months of age) were included in this study. All animals were confirmed to be free of helminths and protozoa by examination of a sample of their faeces using the Willis-Molay and Hoffman et al. techniques (HOFFMANN, 1987).

This experiment involved two experimental groups of rabbits. The first group included 12 females experimentally infected with $T$. canis eggs, 
and the second group, the control group, included five rabbits that were not infected.

Fourteen days preceding the experiment, the animals were kept in individual cages and were handled by researchers each day for 15 minutes, for a period of seven days, to make the animal handling easier during the experimental period (HÕRAK; TUMMELEHT; TALVIK, 2006). The animals were nourished with a commercial feed for rabbits according to the manufacturer's recommendations.

\section{Experimental infection}

The eggs of $T$. canis that were used for animal infection were extracted from adult female worms. The eggs were incubated in $2 \%$ formalin $(1.0 \mathrm{~mL}$ of PBS containing eggs:5.0 mL of formalin) for approximately one month at $28^{\circ} \mathrm{C}$. Following this period, the eggs were washed three times and collected by centrifugation ( 3 minutes at 2,000 rpm). After the washes, 1,000 eggs containing larva were counted in a Neubauer chamber and resuspended in $5.0 \mathrm{~mL}$ of distilled water.

After being mildly anesthetised via intramuscular injection with a $30 \mathrm{mg} / \mathrm{kg}$ tiletamine/zolazepam solution (Zoletil 5\%, Virbac) diluted in saline solution (KANASHIRO; CASSU, 2008), each rabbit was orally infected with eggs via a plastic tube. The control group was inoculated with $5.0 \mathrm{~mL}$ of saline solution following the same anaesthetic procedure.

One month following the infection, 17 pairs of 4-month-old rabbits were mated in separate cages during a three-day period. The rabbits were kept in individual cages during pregnancy and throughout the lactational period. The offspring were allowed to nurse for three weeks, at which time the offspring were separate from their mothers. The mating process was then repeated twice for a total of three consecutive lactations throughout the duration of the study. The pairs (male and female rabbits) remained the same for each mating.

\section{Collect of milk}

After parturition (day 0), milk samples were collected once per day on days 7, 14 and 21. The milk samples (approximately $0.5 \mathrm{~mL}$ ) were obtained by manual milking the teats of the rabbits. To promote the production of a sufficient amount of milk for analysis, the offspring were separated from their mothers for six hours before the milking process.

To obtain serum, blood samples were taken from the experimentally infected and control animals via central ear artery puncture in accordance with the guidelines of the Institutional Animal Care and Use Committee of the University of Iowa (research. uiowa.edu/animal/?get=rbt_tech). Blood samples were collected on days 0 (pre-infection), 7, 14, 21 and 28 post-infection (DPI) and on the first day following the weaning.

\section{Recovery of larvae}

The recovery of $T$. canis larvae was performed by the centrifuge-sedimentation technique described by Ritchie (1948) with slight modifications (HOFFMANN, 1987). Briefly, $500 \mu \mathrm{L}$ of milk was transferred to an Eppendorf tube. An aliquot of $200 \mu \mathrm{L}$ of buffered formalin $7.5 \%(\mathrm{v} / \mathrm{v})$ solution was then added to the milk. The tube was then allowed to stand for 20 minutes. Next, $200 \mu \mathrm{L}$ of sulphuric ether solution was added to the milk solution, and the tube was vigorously shaken for 3 minutes and centrifuged at 2,000 rpm $\left(697 \mathrm{~g} / \mathrm{cm}^{3}\right)$ for 10 minutes (Excelsa Baby II $206 \mathrm{BL}$ - Fanem). After centrifugation, the top layer of ether and the fat plug were separated. Three aliquots of $20 \mu \mathrm{L}$ of the sediment layer from the bottom of the tube were transferred to a glass microscope slide, which was then covered with a glass coverslip $(22$ X 22 $\mathrm{mm}$ ) and examined microscopically (10X and 40X objectives). Third stage larvae were identified according to the morphological characteristics described by Nichols (1956) and Schacher (1957). The specimens recovered from the milk were 
washed in distilled water and preserved at $4^{\circ} \mathrm{C}$ until identification.

\section{ELISA (Enzyme-linked Immunosorbent Assay)}

An indirect ELISA test was performed to evaluate the production of $\operatorname{IgG}$ anti- $T$. canis antibodies according to the protocol described elsewhere (DE SAVIGNY; VOLLER; WOODRUFF, 1979) with slight modifications (ELEFANT et al., 2006).

To perform the test, polystyrene 96-well microplates (Corning, Costar, New York, NY) were coated $(1.9 \mu \mathrm{g} / \mathrm{mL}$ antigen/well) with excretorysecretory antigens produced by $T$. canis larvae (TES) for $2 \mathrm{~h}$ at $37^{\circ} \mathrm{C}$, followed by 18 hours at $4^{\circ} \mathrm{C}$, and then washed three times for 5 minutes with 0.01 $\mathrm{M}$ phosphate-buffered saline, $\mathrm{pH} 7.2$, containing $0.05 \%$ Tween 20 (PBS-T). The microplates were blocked with $2.5 \%$ skim milk (Molico, Nestlé) in PBS-T $(200 \mu \mathrm{g} /$ well $)$ for 1 hour at $37^{\circ} \mathrm{C}$ and then washed three times with PBS-T.

Serum samples $(100 \mu \mathrm{L} /$ well $)$ diluted 1:200 were incubated for 40 minutes at $37^{\circ} \mathrm{C}$. After three wash cycles, the plates were incubated with 1:40,000 horseradish peroxidase-conjugated goat anti-rabbit IgG diluted in PBS-T $(100 \mu \mathrm{L} /$ well; Sigma-Aldrich A0545, USA) for 40 minutes at $37^{\circ} \mathrm{C}$. After a new cycle of washing, the plates were incubated with chromogen solution $(100 \mu \mathrm{L} /$ well; OPD Fast- Sigma, St Louis, USA) composed of ortho-phenylenediamine $(0.4 \mathrm{mg} / \mathrm{mL})$ and $\mathrm{H}_{2} \mathrm{O}_{2}$ urea peroxide $(0.4 \mathrm{mg} / \mathrm{mL})$ in $0.05 \mathrm{M}$ phosphatecitrate buffer for 15 minutes at $37^{\circ} \mathrm{C}$. The reaction was stopped with $2 \mathrm{~N} \mathrm{H}_{2} \mathrm{SO}_{4}(50 \mu \mathrm{L} /$ well $)$, and the optical density was measured at $492 \mathrm{~nm}$ (Titertek Multiskan MCC/340, Lab-System, Finland).

The cut-off value was calculated by adding two standard deviations and the mean absorbance of 17 negative control sera ( 5 controls and 12 pre-infected animals). Antibody levels are expressed as reactivity indices (RIs), which were calculated as the ratio of the absorbance value of each tested sample to the cut-off value (0.292). Samples with RIs greater than 1 were considered positive.

\section{Statistical analysis}

Statistical analysis was performed using the Bioestat 5.0 computational package. The comparison of the number of larvae in different lactations was performed by ANOVA in conjunction with Tukey's method, and the Mann-Whitney test was employed to analyse the averages of the larvae counts at different evaluation time points from the same lactation event. A significance of 5\% was set for all analyses (AYRES et al., 2007).

\section{Ethical considerations}

This study was approved by the Ethical Research Committee of the University of Oeste Paulista, Unoeste, Presidente Prudente, São Paulo, Brazil (132/09).

\section{Results}

In this study, five out of the $12(41.7 \%)$ infected rabbits released T. canis larvae into the milk. All the larvae recovered were immobile and most of them were in a spiral form. The size of the larva was in the range of 0,387 to $0,412 \mathrm{~mm}$ length by 0,015 $0,018 \mathrm{~mm}$ width.

A total of twenty larvae were recovered, equivalent to $0.17 \%$ of the inoculated material (12,000 embryonated eggs). Five larvae were recovered in the first lactation, 10 larvae in the second, and five in the third lactation (Table 1). 
Table 1. The total number of larvae recovered from milk produced by New Zealand female rabbits that were experimentally infected with Toxocara canis embryonated eggs. The larvae were collected via a centrifugesedimentation technique at various lactation time points (7,14 and 21 days) during three different lactation periods.

\begin{tabular}{lcccc}
\hline & \multicolumn{2}{c}{ Time points of milk sample collection } & Total \\
\cline { 2 - 5 } Lactation & +7 & +14 & +21 & 5 \\
1 & 0 & 2 & 3 & 10 \\
2 & 0 & 4 & 6 & 5 \\
3 & 0 & 3 & 2 & 20 \\
\hline
\end{tabular}

Source: Elaboration of the authors.

The presence of larvae in the milk was observed exclusively on the days 14 (nine larvae; 45\%) and 21 (11 larvae; 55\%) of lactation.

The number of recovered larvae ranged from 1 to 4 per lactation/female, and a maximum number of two larvae were observed in a single sample (Table
2). It was observed that with the exception of one animal whose sample milk was considered positive, all rabbits released larvae through their milk at different time points during the same lactation and during two consecutive lactations.

Table 2. The individual numbers of larvae recovered from the milk produced by five of twelve New Zealand female rabbits that were experimentally infected with Toxocara canis embryonated eggs. The eggs were collected via a centrifuge-sedimentation technique at three lactation time points (7, 14 and 21 days) during three different lactation periods.

\begin{tabular}{|c|c|c|c|c|c|c|c|c|c|}
\hline \multirow[b]{3}{*}{ Animal } & \multicolumn{9}{|c|}{ Larvae recovered at three time points during different lactations } \\
\hline & \multicolumn{3}{|c|}{ Lactation 1} & \multicolumn{3}{|c|}{ Lactation 2} & \multicolumn{3}{|c|}{ Lactation 3} \\
\hline & +7 & +14 & +21 & +7 & +14 & +21 & +7 & +14 & +21 \\
\hline 03 & 0 & 0 & 0 & 0 & 1 & 2 & 0 & 2 & 1 \\
\hline 05 & 0 & 0 & 1 & 0 & 0 & 0 & 0 & 0 & 0 \\
\hline 06 & 0 & 0 & 0 & 0 & 1 & 1 & 0 & 1 & 1 \\
\hline 07 & 0 & 2 & 2 & 0 & 1 & 2 & 0 & 0 & 0 \\
\hline 11 & 0 & 0 & 0 & 0 & 1 & 1 & 0 & 0 & 0 \\
\hline
\end{tabular}

Source: Elaboration of the authors.

No difference was observed with respect to the number of larvae during the same lactation $(p=0.7386)$ or with respect to the average number of larvae recovered during different lactations $(p=0.5882)$. Regarding the detection of serum antibodies, 11 infected animals were considered positive based on the ELISA on 28 DPI (IR: 1.3834.639). However, at the time of weaning, antibodies were detected in all of the infected females (IR: 4.557-5.315).
Neither behavioural nor clinical changes were observed in the animals throughout the experimental period.

\section{Discussion}

Milk is an important route of transmission of $T$. canis in dogs (BURKE; ROBERSON, 1985). Some studies in mice have found that $T$. canis larvae are able to migrate from the mother to neonates via suckling, based on the recovery of larvae 
using a tissue digestion technique (REITEROVÁ; TOMASOVICOVÁ; DUBINSKÝ, 2003; JIN; AKAO; OHTA, 2008; DIAS et al., 2010). In our study, the $T$. canis larvae were recovered directly from the milk of experimentally infected rabbits.

Although the murine model has been considered the ideal model for the study of human toxocariasis (BARDÓN; CUÉLLAR; GUILLÉN, 1994), rabbits were utilised in this study because the amount of milk secreted by nursing female rabbits was considered sufficient for the recovery of larvae using the Ritchie technique. This technique is based on centrifuge-sedimentation and is employed for the detection of helminths and protozoan structures in stool samples as part of routine laboratory and epidemiological studies (VALVERDE et al., 2011). The technique involves the use of ether and formalin solutions to dissolve fat elements present in faeces. In our study, these solutions served to promote the lysis of the fat present in milk and the analysis of the sediment. The authors have considered that the larvae may be retained in the fatty layer, thereby making the analysis difficult.

The larvae recovered in our experiment were in an immobile spiral form, probably due to the formalin-ether action. The characteristics of the specimens were similar to the described by Nichols (1956) and Schacher (1957), and the size was in accordance to the observed by these authors and by Rim (1963), who verified a wide variation in size of third stage larvae recovered from tissues.

Further studies are necessary to optimise the technique employed in this experiment. Nevertheless, the technique employed in this study does not require the evaluation of the animal tissues, thereby avoiding the need for euthanasia. Additionally, it was possible to assess the number of larvae released in milk in different lactations.

The number of larvae recovered from the milk, equivalent to $0.17 \%$ of the inoculated material, was considered low. In dogs, Burke and Roberson (1985) observed that the transmission of larvae from nursing females to offspring occurs almost exclusively via the placenta $(98.5 \%)$, whereas only $1.5 \%$ of transmissions occur via milk. In contrast, Tomašovicová et al. (1993) verified in mice that T. canis is primarily transmitted via milk and that uterine migration is sporadic. These conflicting findings suggest that the migrating behaviour of T. canis may vary between the usual and paratenic hosts. In addition, the estimated number of larvae may be influenced by the technique employed for recovery.

Hall (1971) observed that the amount of fat present in the milk of New Zealand rabbits increases gradually throughout the lactation. Thus, a gradual reduction in the number of larvae in milk during the lactation would be expected. However, larvae were not recovered in the first week. Larvae were detected only in the second and the third weeks of nursing with no statistically significant difference. Conversely, Jin, Akao and Ota (2008) recovered larvae from the tissue of mice on days 7 and 14 after birth. Moreover, these authors observed that the number of larvae recovered during the second week was significantly greater than during the first week. After administering prolactin to mice, these authors concluded that this hormone is a promoting factor that contributes to the lactational transmission of $T$. canis larvae in mice. In our study, no substance was administered to the animals to promote the secretion of milk.

Other methodological criteria adopted in experimental studies may influence the evaluation of the migration of $T$. canis larvae, including the number of infective eggs and the gestational and timelines of evaluation. Dias et al. (2010) observed that the infective dosage was directly proportional to the level of transmammary transmission of larvae via milk in mice. These authors infected female adult mice two months before mating, observing that larvae were identified 60 days after birth in $15.2 \%$ and $85.7 \%$ of the mice that nursed from animals infected with 1,200 and 2,500 eggs, respectively. Different from our study, in which 
the larvae were recovered directly from milk, these authors recovered the larvae from the tissues of mice. Regarding the number of larvated eggs, we used 1,000 eggs for infection, that has been widely employed for experimental infection in mice (ABO-SHEHADA; HERBERT, 1984; SAMANTA; ANSARI, 1990; BARDÓN; CUÉLLAR; GUILLÉN, 1994; XI; JIN, 1998; REITEROVÁ; TOMASOVICOVÁ; DUBINSKÝ, 2003; CHO et al., 2007).

In the study of Jin, Akao and Ota (2008), two Balb/c female mice were infected with 300 T. canis eggs 12 hours following the post-puerperal period. A recovery of $18 \%$ of the larvae from the tissue of the offspring was due to mammary transmission. Nevertheless, Reiterová, Tomasovicová and Dubinský (2003) verified that the number of larvae transmitted by milk is independent of the period in which the females are infected (pre or post puerperium).

In the present study, an ELISA test was performed to confirm the infection of the animals, and samples presenting RI values greater than 1 were considered positive. During weaning, antibodies were detected in all infected rabbits (IR: 4.557-5.315), thereby confirming infection.

Our data suggest that the release of $T$. canis larvae via milk may represent an important route of transmission in paratenic hosts. In addition, the technique employed in this study is a feasible tool to recover Toxocara spp. larvae directly from the milk.

\section{References}

ABO-SHEHADA, M. N.; HERBERT, I. V. The migration of larval Toxocara canis in mice II. Post-intestinal migration in primary infections. Veterinary Parasitology, Amsterdam, v. 17, n. 1, p. 75-83, 1984.

ALDAWEK, A. M.; LEVKUT, M.; REVAJOVÁ, V.; KOLODZIEYSKI, L.; SEVEIKOVÁ, Z.; DUBINSKÝ, P. Larval toxocarosis in sheep: the immunohistochemical characterization of lesions in some affected organs. Veterinary Parasitology, Amsterdam, v. 105, n. 3, p. 207214, 2002.
AYRES, M.; AYRES JUNIOR, M.; AYRES, D. L.; SANTOS, A. A. S. Biostat 5.0: aplicações estatísticas nas áreas das ciências biológicas e médicas. Brasília: Sociedade Civil Mamirauá-Belém (MCT-CNPq), Belém. 2007. 364 p.

BARDÓN, R.; CUÉLLAR, C.; GUILLÉN, J. L. Larval distribution of Toxocara canis in BALB/c mice at nine weeks and one year post-inoculation. Journal of Helminthology, London, v. 68, n. 4, p. 357-360, 1994.

BURKE, T. M.; ROBERSON, E. L. Prenatal and lactational transmission of Toxocara canis and Ancylostoma caninum: experimental infection of the bitch before pregnancy. International Journal for Parasitology, Oxford, v. 15, n. 5, p. 71-75, 1985.

CHO, S.; EGAMI, M.; OHNUKI, H.; SAITO, Y.; CHINONE, S.; SHICHINOHE, K.; SUGANUMA, M.; AKAO, N. Migration behaviour and pathogenesis of five ascarid nematode species in the Mongolian gerbil Meriones unguculatus. Journal of Helminthology, London, v. 81, n. 1, p. 43-47, 2007.

DE SAVIGNY, D. H.; VOLLER, A.; WOODRUFF, A. W. Toxocariasis: serological diagnosis by enzyme immunoassay. Journal of Clinical Pathology, London, v. 32, n. 3, p. 284-288, 1979.

DIAS, E. C.; AVILA, L. F. C.; AGUIAR, P. S.; MENDONÇA-SIGNORINI, V. R.; SCAINI, C. J. Transmissão transmamária em camundongos Balb/c com toxocarose crônica. 2010. Disponível em: <http:// www.mpu.furg.br/cd2010/cic/1283.doc >. Acesso em: 5 set. 2011.

ELEFANT, G. R.; SHIMIZU, S. H.; SANCHEZ, M. C.; JACOB, C. M.; FERREIRA, A. W. A serological follow-up of toxocariasis patients after chemotherapy based on the detection of $\operatorname{IgG}, \operatorname{IgA}$ and $\operatorname{IgE}$ antibodies by enzyme-linked immunosorbent assay. Journal of Clinical Laboratory Analysis, New York, v. 20, n. 4, p. 164-172, 2006.

ESPAÑA, A.; SERNA, M. J.; RUBIO, M.; REDONDO, P.; QUINTANILLA, E. Secondary urticaria due to toxocariasis: possibly caused by ingesting raw cattle meat? Journal of Investigational Allergology and Clinical Immunology, Barcelona, v. 3, n. 1, p. 51-52, 1993.

HALL, A. J. Fatty acid composition of rabbit (Oryctolagus cunikulus) milk fat throughout lactation. International Journal of Biochemistry, Bristol, v. 2, n. 10, p. 414-418, 1971.

HOFFMANN, R. P. Diagnóstico de parasitismo veterinário. Porto Alegre: Sulina, 1987. 155 p. 
HÕRAK, P.; TUMMELEHT, L.; TALVIK, H. Predictors and markers of resistance to neurotropic nematode infection in rodent host. Parasitology Research, Berlim, v. 98 , n. 5 , p. $396-402,2006$.

JIN, Z.; AKAO, N.; OHTA, N. Prolactin evokes lactational transmission of larvae in mice infected with Toxocara canis. Parasitology International, Amsterdam, v. 57, n. 4, p. 495-498, 2008.

KANASHIRO, G. P.; CASSÚ, R. N. Anestesia de animais selvagens e de laboratório. In: ANDRADE, S. F. (Ed.). Manual de terapêutica veterinária. 3. ed. São Paulo: ROCA, 2008. p. 727-745.

MAFFRAND, R.; AVILA-VÁZQUEZ, M.; PRINCICH, D.; ALASIA, P. Toxocariasis ocular congénita en un recien nacido prematuro. Anais de Pediatria, Barcelona, v. 64 , n. 6 , p. 595-604, 2006.

MORIMATSU, Y.; AKAO, N.; AKIYOSHI, H.; KAWAZU, T.; OKABE, Y.; AIZAWA, H. A familial case of visceral larva migrans after ingestion of raw chicken livers: appearance of specific antibody in bronchoalveolar lavage fluid of the patients. American Journal of Tropical Medicine Hygiene, Baltimore, v. 75, n. 2, p. 303-306, 2006.

NICHOLS, R. L. The etiology of visceral larva migrans: I. diagnostic morphology of infective second-stage Toxocara larvae. Journal of Parasitology, Lawrence, v. 42, n. 4, p. 349-362, 1956.

PARK, S.; KIM, Y. S.; KIM, Y. J.; KYUNG, S. Y.; PARK, J. W.; JEONG, S. H.; LEE, S. P. Toxocariasis masquerading as liver and lung metastatic nodules in patents with gastrointestinal cancer: clinicopathologic study of five cases. Digestive Diseases and Sciences, New York, v. 57, n. 1, p. 155-160, 2012.

REITEROVÁ, K.; TOMASOVICOVÁ, O.; DUBINSKÝ, $P$. Influence of maternal infection on offspring immune response in murine larval toxocariasis. Parasite Immunology, London, v. 25, n. 7, p. 361-368, 2003.

RIM, H. J. Distribution of the larvae of Toxocara canis and Ascaris lumbricoides in he tissues of mice. Korean Journal of Parasitology, Seul, v. 1, n. 1, p. 37-45, 1963.
RITCHIE, L. S. An ether sedimentation technique for routine stool examination. Bulletin of the United States Army Medical Department, Fort Sam Houston, v. 8, n. 4, p. 326, 1948.

RUBINSKY-ELEFANT， G.; HIRATA， C. E.; YAMAMOTO, J. H.; FERREIRA, M. U. Human toxocariasis: diagnosis, worldwide seroprevalences and clinical expression of the systemic and ocular forms. Annals of Tropical Medicine and Parasitology, London, v. 104, n. 1, p. 3-23, 2010.

SAMANTA, S.; ANSARI, M. Z. Embryonation of ova of Toxocara canis (Werner, 1782) and migration of the larvae in mice. Indian Journal of Animal Science, New Delhi, v. 69, n. 12, p. 1391-1395, 1990.

SANTARÉM, V. A.; RUBINSKY-ELEFANT, G.; FERREIRA, M. U. Soil-transmitted helminthic zoonoses in humans and associated risk factors. In: PASCUCCI, S. (Ed.). Soil contamination. Rijeka: InTech, 2011. p. 4366. Avaliable at: <http://www.intechopen.com/articles/ show/title/soil-transmitted-helminthic-zoonoses-inhumans-and-associated-risk-factors $>$. Accessed at: 31 oct. 2012.

SCHACHER, J. F. A contribution to the life history and larval morphology of Toxocara canis. Journal of Parasitology, Lawrence, v. 43, n. 6, p. 599-612, 1957.

TOMAŠOVICOVÁ, O.; HAVASIOVA-REITEROVA, K.; DUBINSKY, P., HOVORKA, I. Intrauterine and lactogenic transfer of Toxocara canis larvae in paratenic hosts. Helminthologia, Bratislava, v. 30, n. 3-4, p. 111113, 1993.

VALVERDE, J. G.; GOMES-SILVA, A.; DE CARVALHO MOREIRA, C. J.; LELES DE SOUZA, D.; JAEGER, L. H.; MARTINS, P. P.; MENESES, V. F.; BÓIA, M. N. Prevalence and epidemiology of intestinal parasitism, as revealed by three distinct techniques in an endemic area in the Brazilian Amazon. Annals of Tropical Medicine and Parasitology, London, v. 105, n. 6, p. 413-424, 2011.

XI, W. G.; JIN, L. Z. A novel method for the recovery of Toxocara canis in mice. Journal of Helminthology, London, v. 72, n. 2, p. 183-184, 1998.

YOSHIKAWA, M.; KOYAMA, N.; HONTSU, S.; YAMAMOTO, Y.; MIKASA, K.; KIMURA, H. Lessons from eight cases of adult pulmonary toxocariasis abridged republication. Respirology, Carlton, v. 16, n. 6, p. 1014-1015, 2011. 